\title{
A relação entre repetição e religião em Søren Kierkegaard
}

\author{
Presley H. Martins* \\ Renato Kirchner**
}

\section{Resumo}

Nosso objetivo é analisar o conceito de repetição nas obras de Kierkegaard, assim como demonstrar o significado da repetição em sua perspectiva religiosa. É esse sentido religioso que o presente texto pretende investigar, contribuindo, assim, para uma compreensão da religião a partir da experiência da repetição enquanto busca de sentido. Desse modo, o texto apresenta a seguinte estrutura argumentativa: num primeiro momento faremos uma breve apresentação da obra $A$ Repetição, sendo a obra aporética - o conceito de repetição não é explicado pelo autor, propositalmente, em seu sentido mais profundo -, analisaremos nos tópicos seguintes a relação entre a repetição e outros conceitos do autor. A repetição não pode ser compreendida isolada de outros conceitos fundamentais, sendo eles, a saber: fé, instante e amor. Portanto, trataremos de pensar a repetição em articulação com esses conceitos, de tal modo que seja possível compreendermos a repetição na perspectiva religiosa.

Palavras-chave: Kierkegaard; repetição; religião; fé; instante; amor

\section{The Relation Between Repeat and Religion in Søren Kierkegaard}

\footnotetext{
Abstract

Our objective is to analyze the concept of repetition in Kierkegaard's works, as well as to demonstrate the meaning of repetition in his religious perspective. It is this religious meaning that this text intends to investigate, thus contributing to an understanding

* Universidade Federal de Juiz de Fora (UFJF). Doutorando em Ciência da Religião pela Universidade Federal de Juiz de Fora (UFJF). Mestre em Ciências da Religião e licenciado em Filosofia, ambos pela PUC-Campinas. Lattes: http://lattes.cnpq.br/7971420151682616. presley.hmartins@gmail.com

** PUC-Campinas. Doutor em Filosofia pela UFRJ, professor em cursos de graduação e pesquisador do Programa de Mestrado Strico Sensu em Ciências da Religião na Pontifícia Universidade Católica de Campinas (PUC-Campinas). Lattes: http://lattes.cnpq. br/5079313371476684.renatokirchner@puc-campinas.edu.br.
} 
of religion from the experience of repetition as a search for meaning. Thus, the text presents the following argumentative structure: at first we will make a brief presentation of the work The Repetition, being the aporetic work - the concept of repetition is not explained by the author, on purpose, in its deepest sense -, we will analyze in the topics following the relationship between repetition and other concepts of the author. Repetition cannot be understood in isolation from other fundamental concepts, namely: faith, instant and love. Therefore, we will try to think of repetition in conjunction with these concepts, in such a way that it is possible to understand repetition from a religious perspective.

Keywords: Kierkegaard; repetition; religion; faith; instant; love

\section{A Relación entre Repetición y Religión en Søren Kierkegaard}

\section{Resumsen}

Nuestro objetivo es analizar el concepto de repetición en las obras de Kierkegaard, así como demostrar el significado de la repetición en su perspectiva religiosa. Es este sentido religioso el que este texto pretende investigar, contribuyendo así a una comprensión de la religión desde la experiencia de la repetición como búsqueda de sentido. Así, el texto presenta la siguiente estructura argumentativa: en un primer momento haremos una breve presentación de la obra La repetición, siendo la obra aporética - el concepto de repetición no es explicado por el autor, en su sentido más profundo - analizaremos en el temas siguiendo la relación entre repetición y otros conceptos del autor. La repetición no puede entenderse aislada de otros conceptos fundamentales, a saber: fe, instante y amor. Por tanto, intentaremos pensar en la repetición en conjunto con estos conceptos, de tal forma que sea posible entender la repetición desde una perspectiva religiosa.

Palabras clave: Kierkegaard; repetición; religión; fe; instante; amor

\section{Introdução: estrutura da obra $A$ Repetição}

Em 16 de outubro de 1843, Kierkegaard publicou $A$ Repetição, sob o pseudônimo Constantin Constantius, Temor e tremor, sob a pena de Johannes de Silentio, e Três discursos edificantes, assinados pelo próprio nome. A publicação conjunta das obras não foi meramente casual, uma vez que os temas tratados nesses textos se comunicam mutualmente. A publicação dessas obras se inserem num contexto especifico na vida de Kierkegaard, cuja exposição contextualiza temas importantes que serão fundamentais às obras de 1843. Em setembro de 1840, Kierkegaard anunciou seu noivado com Regine, com quem rompeu um ano depois. Naquele mesmo ano, em 1841, Kierkegaard deixou Copenhague e foi para Berlim com o objetivo de assistir a uma série de palestras dadas por Schelling (GARDINER, 2013, p.17). Em 1843, Kierkegaard faz uma segunda viagem à Berlim, é a partir da 
experiência dessa segunda viagem que Kierkegaard irá escrever a repetição. Vale ressaltar que, na obra, Constantin Constantius também realiza a mesma viagem com o objetivo de experimentar a repetição. Durante todo esse tempo Kierkegaard jamais se esqueceu de Regine. Foi durante sua segunda ida à Berlim que Kierkegaard escreveu A Repetição. Acredita-se que pretendia reatar seu noivado com Regine quando retornasse à Copenhague (GARFF, 2017).

De acordo com Joakim Garff (2017), na obra Kierkegaard's Muse: The Mystery of Regine Olsen ${ }^{1}$, Kierkegaard escreve, segundo uma carta enviada em 25 de maio de 1843 para Boesen, que o manuscrito estava "finalizado". O manuscrito em questão tratava-se de $A$ Repetição. Contudo, ao descobrir que Regine ficara noiva de Johan Frederik Schlegel, Kierkegaard percebeu a necessidade de revisar a obra e o próprio conceito de repetição. Passou os meses de verão daquele ano reescrevendo, em especial, a segunda parte da obra. Na primeira versão de $A$ Repetição, o Jovem apaixonado, personagem do livro, comete suicídio após perceber a falha da repetição, que até então estava sendo tratada como uma repetição mecânica. A impossibilidade da repetição culmina no suicídio do jovem. Na segunda versão, Kierkegaard trabalhou para dar um final diferente para o jovem: lhe trouxe de volta à vida, tendo um desfecho diferente: o Jovem adquiri uma nova perspectiva sobre a repetição, a partir de sua experiência com o livro de Jó. Portanto, é somente nessa segunda versão que a repetição ganha seu sentido mais profundo e religioso. Diante desse contexto, é intrigante o fato de ser justamente onde não há esperança, em que toda certeza se encontra abandonada pela impossibilidade, que Kierkegaard encontra um novo sentido para a repetição. Nesse sentido, até a repetição teve uma repetição.

Segundo Garff (2017, p. 123), a repetição é algo tão esquisito quanto um pedaço de confessionário literário assinado pseudonimamente e que distribui a própria experiência de Kierkegaard, referente ao noivado rompido

A musa de Kierkegaard: o mistério de Regine Olsen (tradução própria).

Os materiais textuais sobreviventes não permitem qualquer reconstrução real da gênese da obra, mas é claro que Kierkegaard se sentiu compelido a revisar e estender sua história, fazendo mudanças drásticas na trama. O jovem, originalmente, supostamente teria cometido suicídio, e presumivelmente ele estava nesse estado sem vida quando chegou a Copenhague (GARFF, 2007, p. 245, tradução própria). Na tradução consultada: “The surviving textual materials do not permit any real reconstruction of the work's genesis, but it is clear that Kierkegaard had felt himself compelled to revise and extend his tale, making drastic changes in the plot. For the Young Man was originally supposed to have committed suicide, and it was presumably in this lifeless state that he arrived in Copenhagen. " 
com Regine Olsen, entre duas figuras ficcionais: Constantin Constantius e o Jovem. Uma das grandes dificuldades em se ler uma obra como A Repetição está no fato de não ser uma obra expositiva conceitual. Sua pretensão não é nos explicar sistematicamente um conceito, mas aplicar à existência o que está sendo elaborado.

A obra se aproxima do gênero romance, com personagens e uma narrativa que se confunde com a biografia do próprio autor. O gênero traça sua originalidade, o conceito se movimenta por forças da própria existência e, por isso, é uma experiência. Tendo em vista que a repetição está atrelada à experiência, a obra, portanto, utilizando-se de um conceito de Deleuze, é operada por personagens conceituais. Os personagens conceituais são "os verdadeiros sujeitos de sua própria filosofia. Os personagens conceituais são os heterônimos do filósofo" (DELEUZE, 2010, p. 75-78).

Sabe-se que do mesmo modo que o próprio conceito de repetição sofreu uma revisão em virtude de Kierkegaard não poder reatar seu noivado com Regine, na obra $A$ Repetição, o jovem só irá encontrar a repetição mediante a expressão religiosa que confere ao conceito, logo após ter perdido a Jovem por quem estava apaixonado. Semelhante a Jó que sentiu-se abandonado por Deus e foi abandonado pelos amigos, o Jovem encontrase com o seu mundo devastado e com a falta de sentido. Portanto, o que está em jogo na repetição é a falta de sentido que, no limite, ocorre por sua própria impossibilidade: a impossibilidade de repetir algo que se perdeu. É nesta perspectiva que Constantius diz: "a repetição é a realidade, e é a seriedade da existência. Aquele que quer a repetição amadureceu em seriedade" (KIERKEGAARD, 2009a, p. 33). Como vimos, na primeira versão da obra, o jovem se suicida pelo fato de não conseguir realizar a repetição. A falta de sentido do jovem foi devido ao seu fracasso no amor. Segundo Garff, a primeira versão tinha o intuito de se comunicar com Regine:

O suicídio foi uma mensagem mais ou menos indireta para Regine de que se houvesse alguma repetição de seu relacionamento, então um milagre era necessário, uma intervenção divina, que o livro colocou de forma mais contundente ao dizer que teria que ser em virtude do absurdo - como aconteceu no caso de Jó, que recuperou tudo em dobro (GARFF, 2017, p. 87 , tradução própria) ${ }^{3}$

\footnotetext{
3 Na tradução consultada: "The suicide was a more or less indirect message to Regine that if there should be any repetition of their relationship, then a miracle was needed, a divine intervention, which the book put more pointedly by saying it would have to be by virtue of the absurd-as happened in the case of Job who got everything back twofold."
} 
Ao alterar a versão original, Kierkegaard não só nos entregou uma nova concepção sobre a repetição, mas, mais do que isso, ele demonstrou indiretamente como que sua própria experiência, diante da impossibilidade objetiva, trouxe para si um sentido que antes não existia. Todavia, se a repetição produziu a falta de sentido em sua impossibilidade, foi a própria repetição que prospectou sentido na sua possibilidade mais própria, que não é possível obter na sua imediaticidade. Portanto, por não conseguir a repetição, o Jovem perde o sentido de sua existência. E para recuperar o sentido é, ao mesmo tempo, necessário a repetição.

Logo nas primeiras linhas de A repetição, Constantin Constantius anuncia sua obsessão com a repetição. Sua ideia é descobrir se a repetição é possível. Sua vontade de experimentar a repetição se caracteriza como uma psicologia experimental, que consta no subtítulo da obra. Constantin Constantius diz ter se ocupado durante muito tempo com o problema da repetição, queria saber se uma repetição era possível e qual seria seu significado. A ideia o atormentava a ponto de o deixar paralisado em torno deste problema; o problema do que se ganha e o que se perde ao repetir-se (KIERKEGAARD, 2009a, p. 31).

A obra se divide em duas partes. Na primeira parte acompanhamos um jovem apaixonado que procura a ajuda de Constantin Constantius, pois esse jovem se encontra em perdido em relação à sua amada. Ela o inspira de tal forma que o torna poeta; porém, não consegue manter a relação com a jovem, pois, a cada dia, tudo é diferente entre eles; o Jovem não consegue viver além das lembranças sublimes de uma relação profunda de amor verdadeiro. Constantin Constantius sugere ao jovem realizar a repetição. Nesse sentido, caberia ao Jovem fazer com que ela terminasse com ele, para depois, tentar recuperar o que fosse e estava sendo perdido. O jovem não segue o conselho e desaparece, meses depois volta a se comunicar por cartas com Constantius. O próprio Constantius tenta realizar a repetição refazendo uma viagem até Berlim. Constantius procura assistir a mesma peça que havia visto na primeira vez. E para sua surpresa, toda a viagem fora desastrosa, tudo era diferente, não conseguiu se divertir com a peça como da primeira vez. O hotel não era tão aconchegante e não reencontrara com uma jovem, aquela que havia visto em sua primeira viagem. A repetição até então, vista pelo pseudônimo, fora uma repetição baseada na recordação, que busca viver o mesmo com base em uma experiência significativa e profunda. Na segunda parte da obra, o Jovem volta a comunicar-se com Constantius através de cartas. Nas cartas, o 
jovem diz que sua amada estava comprometida com outro. O Jovem diz que sua existência perdera o significado. Após experimentar a falta de sentido, em outras cartas, escreve a Constantius que encontrou em Jó o que precisava para voltar a ser ele mesmo novamente.

O nome Constantin Constantius faz referência à repetição, segundo Mooney: "O nome, toma nota, é ele mesmo uma repetição. Ele recria com o mesmo nome a tensão entre algo constante (o elemento a ser repetido) e o movimento (algo repetido). E se investigarmos mais, há várias pistas para repetição contidas na escolha do pseudônimo de Kierkegaard" (MOONEY, 2006, p. 285, tradução própria). Mooney desenvolve algumas reflexões sobre o sentido da repetição contido no nome do pseudônimo. Ele aponta que Constantin Constantius pode ser aquele que se mantém firme, constante, como um pilar de força com quem o jovem - que está abalado e sofre por sua perda - pode contar; nesse sentido Constantius parece ser aquele que é "constante". Outra possibilidade, segundo Mooney, refere-se a Constantin Constantius ser aquele que busca alcançar a repetição, em outras palavras, ser aquele que procura constância. Afinal, é Constantin Constantius que pensa na repetição de forma teórica e é ele que faz a experiência psicológica de buscar reviver uma experiência de viagem que fizera à Berlim (2006, p. 285).

Edward F. Mooney, em seu artigo Repetição: recuperando o mundo de volta ${ }^{4}$, busca relacionar as obras Temor e tremor e $A$ repetição tendo como pano de fundo o contraste entre a perda inesperada e o anseio de restauração. Abraão, em sua provação, deve sacrificar seu filho, Isaac. O filho da promessa de Deus para com Abraão. Abraão não poderia esperar que lhe fosse ordenado sacrificar o próprio filho, ainda mais tratando-se do filho prometido, o filho da velhice, que durante muito tempo Abraão o aguardou pacientemente. Mas o sacrifício foi ordenado. Abraão só poderia caminhar três dias até Moriá acreditando, que de alguma forma, ele poderia recuperar Isaac, mesmo tratando-se de algo impossível objetivamente. Jó, em sua provação, é despojado de seu mundo, perde sua saúde, os filhos, os animais, ele não é compreendido por seus amigos e esposa, mas sabe que é inocente, que nada fez para merecer toda aquela aflição e sofrimento. Mooney diz que "a questão posta pela repetição é se a repetição é possível, se o mundo ou aquele a quem se ama, agora perdido, pode ser restaurado ${ }^{5 "}$ (MOONEY, 2006, p.

Título original: Repetition: Getting the world back

No original: "The question posed by repetiton is whether repetition is possible, whether a world or loved one, now lost, can be restored. “ 
282, tradução própria). Portanto, é sob essa perspectiva de restauração que procuraremos compreender a repetição a partir da relação entre a repetição e Jó, a repetição e a fé, a repetição e o instante e a repetição e o amor.

\section{Jó e a Repetição}

Após o Jovem ter desaparecido e retornado a conversar com Constantius através de cartas, o Jovem diz ter encontrado a repetição em Jó: "Job é bendito e recebeu tudo em dobro - A isto chama-se uma repetição" (KIERKEGAARD, 2009a, p. 23). Jó, como se sabe, perdeu tudo: seus animais, sua colheita, seus filhos, sua saúde. Jó não compreendia o porquê aquilo estava acontecendo com ele. Seus os amigos o acusaram, dizendo que ele havia cometido alguma falta contra Deus. Portanto, para esses amigos, Jó estava sendo castigado. Diante dessa situação é incompreensível o sofrimento de Jó. O que admira o Jovem na história de Jó foi ele ter se mantido firme diante da situação de sofrimento (KIERKEGAARD, 2009a, p. 18-19). Jó permaneceu firme na sua afirmação: "Job mantém-se firme na sua afirmação, fazendo-o de tal maneira que nele são visíveis o amor e a confiança que estão convictos de que Deus pode sempre resolver tudo, bastando que possa falar-se diretamente com ele" (KIERKEGARRD, 2009a, p. 118). Jó, portanto, tinha confiança de que tudo poderia ser resolvido, pois sabia que não havia cometido nenhuma injustiça. Não abandonou sua fé, por mais que todos dissessem que ele havia cometido alguma falta contra Deus. O que o Jovem percebe nessa narrativa bíblica foi que todo o sofrimento foi travado na interioridade de Jó:

Assim, a grandeza de Job não reside sequer em ter dito: o Senhor o deu e o Senhor o tomou, bendito seja o nome do Senhor; algo que na verdade disse a princípio e que não repetiu mais tarde. A importância de Job reside antes em as disputas de fronteiras a respeito da fé ter sido travada dentro de si próprio, em nos ser aqui apresentada a monstruosa sublevação das forças selvagens e belicosas da paixão (KIERKEGAARD, 2009b, p. 120)

Nos Quatro Discursos Edificantes de 1843, no discurso intitulado O Senhor o deu e o Senhor o tomou; bendito seja o nome do Senhor; Kierkegaard diz que mesmo Jó tendo perdido tudo, sofrendo, ao mesmo tempo diz "bendito seja o nome do senhor" (cf. Jó 1:21). Se qualquer outro tivesse dito isso, a frase não seria significativa. A declaração de Jó é significativa porque foi pronunciada por Jó. Uma vez que ele passou por todo o sofrimento, aceitando tudo o que Deus havia dado e retirado, a declaração de Jó tem conteúdo, tem concretude. 
A ficção de forma alguma consiste no que ele disse, mas no que ele fez. Ele realmente deixou uma declaração que por sua brevidade e beleza tornou-se um provérbio preservado de geração em geração, e ninguém presunçosamente acrescentou nada a ele ou tirou nada dele; mas a afirmação em si não é o guia, e o significado de Jó não consiste em tê-la dito, mas em ter agido de acordo com ela. O ditado em si é certamente bonito e vale a pena ponderar, mas se outra pessoa o tivesse dito, ou se Jó fosse outra pessoa, ou se ele o tivesse dito em outra ocasião, o ditado em si também teria se tornado algo diferente - significativo, se tinha qualquer significado, como falado, mas não significativo porque ele agiu afirmando ${ }^{6}$ (KIERKEGAARD, 1992, p.109)

Portanto, Jó agiu afirmando. É isso que torna sua declaração significativa. Nesse sentido, é extremamente fundamental ponderar sobre o significado de Jó; sobre o que Jó representa para humanidade. Todos os seres humanos vivem neste mundo contingente. Todos nós podemos ser surpreendidos pelo sofrimento: um acidente, uma doença, a perda de entes queridos, tudo isso pode acontecer. Uma vez que a contingência age em nosso mundo, podemos perceber como tudo está, a cada momento, por um fio. Nos engamos quando pensamos diferente, e, quando acontece, somos pegos pelas costas e o sofrimento entra na alma como uma adaga aguda e afiada penetra no corpo. Jó não esperava que fosse acontecer o que aconteceu. Mas aconteceu. O sofrimento foi imprevisível. No mundo material não temos nada garantido, no espiritual podemos receber o mundo perdido. Mas isso não é tão simples. Jó experimentou o horror, sobreviveu a ele, e tudo aconteceu para o nosso próprio benefício, porque agora podemos olhar para Jó e melhor compreender nosso mundo.

O Jovem havia perdido tudo, perdeu a si mesmo, porque, antes de tudo, quando se perde algo, é sempre algo de si. Desse modo, o que o Jovem encontrou em Jó foi a si mesmo novamente. O Jovem foi confortado por Jó, porque este superou sua dor.

Mas se o único indivíduo experimenta o terror em pensamento, está

6 Na tradução consultada: "ficance by no means consists in what he said but in what he did. He did indeed leave a statement that by its brevity and beauty has become a proverb preserved from generation to generation, and no one has presumptuously added anything to it or taken anything from it; but the statement itself is not the guide, and Job's significance consists not in his having said it but in his having acted upon it. The saying itself is certainly beautiful and worth pondering, but if someone else had said it, or if Job had been someone else, or if he had said it on another occasion, the saying itself would also have become something different-meaningful, if it had any meaning at all, as spoken, but not meaningful because he acted by asserting" 
angustiado com o pensamento do horror e angústia que a vida pode ter reservado, com o pensamento de que ninguém sabe quando a hora do desespero pode chegar para ele, então seu pensamento perturbado procura Jó, repousa nele, é por ele acalmado, pois Jó o acompanha e conforta fielmente, não, com certeza, como se ele tivesse sofrido de uma vez por todas o que nunca mais sofreria, mas conforta como alguém que testemunha que o horror foi sofrido, o horror foi experimentado, a batalha do desespero foi travada para a glória de Deus, para seu próprio resgate, para o benefício e alegria de outros $^{7}$ (KIERKEGAARD, 1992, p. 110)

A tristeza e o sofrimento que irrompem na vida, não fizeram da existência de Jó uma existência sem sentido. Jó não precisou esperar sua vida consumar e olhar para trás para perceber se sua vida teve ou não sentido. Jó manteve-se firme, paciente e acreditava que tudo se resolveria. Ele acreditava na justiça de Deus. "Portanto, quando Jó disse: 'O Senhor deu', sua mente estava bem preparada para agradar a Deus também com as palavras seguintes, 'O Senhor levou embora ${ }^{8}$.' " (KIERKEGAARD, 1992, p. 117).

Por conseguinte, o fato de Jó ter sido feliz antes do sofrimento é uma característica importante para compreensão da provação de Jó. Se alguém é infeliz sem ter conhecido a felicidade, talvez pouco possa no falar sobre o significado da dor. Mas Jó contrasta sua situação de sofrimento com os seus dias alegres, mas sem perder sua confiança no presente:

Talvez tenha havido alguém que no dia da tristeza também se lembrou de ter conhecido dias felizes; então sua alma ficou ainda mais impaciente. "Se ele nunca tivesse conhecido a felicidade, então a dor não o teria subjugado, pois o que é a dor é uma ideia que a pessoa que nada mais conhece não tem, mas agora é justamente a alegria que o educou e o desenvolveu para perceber a dor. " Então sua alegria se tornou sua própria ruína; nunca se perdeu, mas apenas faltou, e em sua falta o tentou mais do que nunca. O que tinha sido o deleite de seus olhos, seus olhos ansiavam por ver de novo, e sua ingratidão o

\footnotetext{
Na tradução consultada: "but if the single individual experiences the terror in thought, is anguished over the thought of what horror and distress life can have in store, over the thought that no one knows when the hour of despair may strike for him, then his troubled thought seeks out Job, rests in him, is calmed by him, for Job faithfully accompanies him and comforts him, not, to be sure, as if he had suffered once and for all what would never be suffered again, but comforts as someone who witnesses that the horror has been suffered, the horror has been experienced, the battle of despair has been fought to the glory of God, for his own rescue, for the benefit and joy of others"

8 Na tradução consultada: "Therefore, when Job had said, 'The Lord gave,' his mind was well prepared to please God also with the next words, 'The Lord took away."'
} 


\section{Presley H. Martins \\ Renato Kirchner}

puniu induzindo-o a acreditar que era mais bonito do que nunca. O que sua alma tinha se deleitado agora tinha sede, e a ingratidão o punia por retratá-lo como mais delicioso do que nunca. O que antes tinha sido capaz de fazer, agora queria ser capaz de fazer de novo, e a ingratidão o punia com fantasias que nunca tiveram qualquer verdade ${ }^{9}$ (KIERKEGAARD, 1992, p. 117)

Portanto, o indivíduo que teve a felicidade em sua vida, no momento do sofrimento, anseia por tê-la novamente, uma vez que está perdida. No sofrimento anseia pela felicidade. Na repetição sua alegria é em dobro. Jó não perdeu a paciência, por isso não sofreu com os contrastes dos dias alegres, sua consciência sabia que Deus poderia dar e retirar. Jó não foi ingrato, porque disse "bendido seja o nome do senhor". E por isso recebeu tudo em dobro.

Não haverá então repetição? Não recebi tudo a dobrar"? Não me recebi a mim mesmo de volta e precisamente de tal maneira que fui obrigado a sentir duplamente o significado desse facto? E que é a repetição de bens terrenos, que são indiferentes no que respeita à determinação do espírito, quando comparada com uma repetição como esta? Job só não recebeu os filhos a dobrar, porque uma vida humana não pode ser duplicada assim. Aqui só é possível a repetição do espírito, embora nunca seja tão perfeita na temporalidade como na eternidade, que é a verdadeira repetição (KIERKEGAARD, 2009a, p. 132).

Mas o que poderá significar receber tudo em dobro? É a temporalidade retomada, o histórico ressignificado, nos termos que veremos no tópico seguinte, é retornar à temporalidade depois de a ela ter se abdicado. Assim, tudo é recuperado em dobro. Ganha-se duas vezes o que se perdeu. Podemos pensar aqui, e será fundamental para o nosso último tópico, que ver o outro na finitude, depois de ter passado pela infinitude, é vê-lo na sua singularidade como próximo.

9 Na tradução consultada: "Perhaps there was someone who on the day of sorrow also recalled that he had known happy days; then his soul became even more impatient. "If he had never known happiness, then the pain would not have overwhelmed him, for what is pain but an idea that the person who knows nothing else does not have, but now it is precisely joy that has educated and developed him to perceive pain." Then his joy became his own ruin; it was never lost but only lacking, and in its lack it tempted him more than ever before. What had been his eyes' delight, his eyes craved to see again, and his ingratitude punished him by inducing him to believe it to be more beautiful than it had ever been. What his soul had delighted in, it now thirsted for, and ingratitude punished him by picturing it to him as more delightful than it had ever been. What he once had been able to do, he now wanted to be able to do again, and ingratitude punished him with fantasies that had never had any truth" 
O Jovem diz em sua última carta a Constantius: "Sou de novo eu mesmo; a maquinaria foi posta em movimento. Desfeitos estão os laços em que me encontrava preso; quebrada está a fórmula mágica que me embruxava de tal modo que não conseguia voltar a mim" (KIERKEGAARD, 2009a, p. 132). Assim, o jovem recuperou a si mesmo e fez isso ponderando sobre Jó. Ao voltar a ser ele mesmo novamente, o Jovem pôde nascer de novo.

Nos tópicos seguintes abordaremos temas que são fundamentais para uma melhor compreensão da repetição. A fé enquanto duplo movimento é o que possibilita a retomada à temporalidade. $\mathrm{O}$ instante, o paradoxo absoluto, requalifica a subjetividade e devolve a liberdade ao indivíduo. $\mathrm{O}$ amor, a partir de seu dever, dá continuidade na existência, sendo o mesmo na multiplicidade. Nesse sentido, retira a vida do hábito e confere sentido à existência.

\section{Fé e Repetição}

Doravante, analisaremos a relação entre fé e repetição, a fim de compreendermos de que forma a fé e a repetição estão relacionadas e unem finitude e infinitude. Para Gouvêa: "apresentar a compreensão de Kierkegaard sobre fé significa apresentar sua visão do que é verdadeiramente o cristianismo" (GOUVÊA, 2000, p. 118).

Na obra Temor e tremor, publicada em 1843, Kierkegaard, sob a pena de Johannes de Silentio, narra a Aquedah, o caminho que Abraão percorreu até Moriá, seguindo a ordem de Deus para sacrificar seu próprio filho, Isaac. Johannes de Silentio, rumina a narrativa bíblica e não consegue compreender a fé de Abraão. O filho da promessa, vindo na velhice, haveria de ser sacrificado como prova de fé. E "Abraão levantou-se cedo, mandou aparelhar os jumentos, deixou a tenda e levou Isaac consigo..." (KIERKEGAARD, 2009b, p. 58). Abraão sacrificaria seu filho, levaria às últimas consequências o que fora ordenado por Deus.

Johannes de Silentio, logo de início, questiona se não avançamos a partir do ponto que mais deveríamos ponderar. É justamente o que Johannes fará: ponderar sobre a fé de Abraão, sobre a tensão entre sua esperança de voltar com Isaac e ter que sacrificá-lo. Será que realmente alguém sabe o que diz quando fala sobre fé? Pois Abraão estava disposto a sacrificar aquilo que mais amava e o fruto da promessa que tanto aguardou na esperança. A fé de Abraão o fez amarrar o burro e caminhar três dias até Moriá, caminhar três dias ao lado de quem mais amava e subir a montanha com o intuito de imolar o filho. Abraão não pôde contar a Sara sobre sua tarefa, seria 
incompreendido e até poderia ser considerado como louco. Diante da lei que diz "não matarás", Abraão não pôde se justificar, tampouco pelo dever que o pai tem de amar seu filho.

Johannes não se considera um filósofo, mas um escritor extraordinário: "O presente autor não é de todo filósofo, não entendeu o sistema, nem se o sistema existe ou se já acabou [...]” (KIERKEGAARD, 2009b, p. 52). Johannes considera-se apenas um escritor, um poeta, o que podemos compreender como gênio da recordação. A fé, sendo uma categoria religiosa, não poderia ser exposta sistematicamente, pois cabe aqui ponderar: "Apesar de se encontrarem reunidas as condições para transpor todo o conteúdo da fé para a forma de conceito, tal não levou a que se entendesse a fé, a que se entendesse como se entrou na fé ou como a fé entrou em cada um" (KIERKEGAARD, 2009b, p. 52). Cabe a ele lembrar e contar a narrativa bíblica, mas sem reduplicar em sua existência aquilo que está narrando. Diferente de Constantius que ao mesmo tempo em que delibera sobre a repetição, busca executá-la. Se o jovem, considerado poeta, também foge da proposta de Constantius de realizar a repetição, posteriormente será ele, o jovem, a recordar a provação de Jó. Compreender a fé baseando-se em um sistema, seria perder o próprio sentido da fé. Portanto, são nas palavras do poeta que o religioso ganha sua expressão e se torna conhecido, são nas palavras do poeta que os grandes feitos do herói não caem no esquecimento.

Mas é por isso que assim não é, e tal como Deus criou o homem e a mulher, concebeu o herói e o poeta ou o orador. Não cabe ao poeta fazer o que faz o herói, pode apenas admirar, amar, e alegrar-se por intermédio do herói. Contudo o poeta também é afortunado, e não menos que o herói; pois que o herói é por assim dizer a sua melhor essência, pela qual se sente apaixonado e feliz por não ser no entanto ele próprio o herói, feliz porque seu amor pode ser admiração. O poeta é o gênio da recordação, nada pode fazer sem lembrar o que foi feito, nada faz sem admirar o que foi feito; nada tira de si mesmo, mas é cioso do que lhe foi confiado. Segue o que lhe dita o coração, mas quando encontrou o que procurava, caminha então de porta e canta e declama, para que todos possam admirar o herói como ele, e do herói sintam orgulho. (KIERKEGAARD, 2009b, p. 65/66)

O poeta e o Herói dependem um do outro, ambos devem realizar tarefas distintas, mas essas tarefas não estão separadas. O poeta é o gênio da recordação, só pode recordar do que foi feito. Mas recordar é diferente de repetir, de realizar o novo. Não cabe ao poeta realizar, como Abraão, o 
movimento da fé. O próprio Johannes de Silentio encarna na obra a figura do poeta, admirando e exaltando Abraão, enquanto ele mesmo diz não ser capaz de ter a fé que Abraão teve. Após fazer essa separação, podemos concluir que o poeta cumpre o papel da recordação da história universal, situado, ainda, na superficialidade geral. Esse ponto fica mais claro na Expectoração preliminar. Nesse capítulo, Johannes fala sobre um pastor que no domingo fala sobre a experiência de fé de Abraão, porém, na segunda-feira, um fiel aparece na igreja dizendo ao pastor que, para provar sua fé, realizará o mesmo movimento de Abraão. O que aconteceria com tal fiel? O que o pastor falaria para ele? É certo que o pastor o impediria. Caso o fiel ignorasse o conselho do pastor e, mesmo assim, quisesse levar a cabo suas intenções, o fiel seria considerado um louco e provavelmente seria preso. Mas, ao proceder desse modo, estaria o pastor tendo consciência do movimento da fé realizado por Abraão? Teria alcançado a profundidade dessa experiência, para falar dela como se fala de qualquer outra? E o fiel, se o consideramos como louco, por que dizemos que Abraão é o pai da fé? O que difere Abraão dos demais? Abraão não se justifica pela razão, pois pela razão poderíamos também atribuir à sua provação uma loucura. Mas ainda assim Abraão é o pai da fé. A fé está além da racionalidade, o limiar dessa experiência é o paradoxo.

O paradoxo da fé consiste no facto de o singular ser superior ao universal, no facto de o singular, recordando uma distinção dogmática agora ainda mais rara, determinar a sua relação com o universal através da sua relação com o absoluto, e não sua relação com o absoluto através da sua relação com o universal. Pode também exprimir-se o paradoxo como sendo um dever absoluto para com Deus; pois nesta relação de dever, o singular, na sua qualidade de singular, relaciona-se de maneira absoluta com o absoluto. Quando a este propósito se afirma que é dever amar a Deus, afirma-se, portanto, uma coisa diferente do que foi dito anteriormente; pois que este dever é absoluto, o ético ficará, portanto, reduzido ao relativo. Não se conclua porém que o dever tem de ser suprimido, antes recebe a expressão inteiramente diferente, a expressão paradoxal, da mesma forma que o amor a Deus, por exemplo, pode levar o cavaleiro da fé a dar ao seu amor pelo próximo a expressão oposta àquela que eticamente falando constitui seu dever. (KIERKEGAARD, 2009b, p. 130)

Podemos constatar nessa passagem, entre o universal e o absoluto, o problema e a necessidade da justificação, assim como a delimitação que a ética, indispensavelmente, recebe de uma relação ulterior e injustificável 
entre o singular e o universal. A relação entre o singular e o absoluto, sem a mediação ética, é o paradoxo da fé. Pela ética o singular se justifica de forma universal; pela fé, o singular se coloca acima do universal (da ética) e, então, ao realizar essa nova relação, ocorre o paradoxo. Toda ação ética se justificava pelo universal, nesse sentido, pela ética. Assim, se a fé fosse caracterizada pela relação ética com o absoluto, a relação seria ética e não propriamente religiosa, pois a universalidade repete as ações éticas e, assim, são justificáveis. Kierkegaard nos chama atenção para a diferença e a univocidade relacional do singular na sua relação com o absoluto, extraindo dessa relação o significado que a fé tem para o indivíduo. Segundo Roos: "O que está em jogo com relação a este conceito de fé é a totalidade do ser humano e das esferas que o constituem" (ROOS, 2019, p. 20). Isso significa que a fé não desconsidera o ético para ser religiosa. Caso o ético fosse desconsiderado, Abraão poderia, sem culpa, sacrificar seu filho. No entanto, o que Abraão sente é justamente a tensão entre o ético e religioso.

Assim, é pela justificação que o ético tem seu sentido, do mesmo modo que é pela sua regularidade que ela tem a pretensão teórica de resolver e eliminar a imprevisibilidade situacional e relacionais das contingências externas à existência, fornecendo ao indivíduo o parâmetro para se agir e se viver. Sem o elemento ético a trajetória de Abraão não seria uma provação. "Na história de Abraão encontramos um paradoxo deste gênero. Expressa eticamente, a sua relação com Isaac é: o pai deve amar o filho. Esta relação ética reduz-se a uma relação relativa em contradição com a relação absoluta com Deus” (KIERKEGAARD, 2009b, p. 131).

O problema da justificação decorre da relação absoluta com o absoluto que não se justifica universalmente, a necessidade dessa relação injustificável subjaz no caráter específico da religião enquanto fundamento da existência. O indivíduo diante de Deus, relacionando-se de forma totalmente única com o absoluto, faz uma relação própria com o universal; pois se essa relação fosse determinada pelo universal, jamais seria uma relação própria. A relação se estabelecer-se-ia de modo determinado e o caráter singular seria então diluído. A fé, enquanto paradoxo, é impreterivelmente injustificável, pois "a própria fé não pode estar sujeita à mediação no universal, pois seria anulada através dele. A fé é este paradoxo e o singular não pode fazer-se entender seja por quem for" (KIERKEGAARD, 2009b, p. 131).

Johannes de Silentio interroga-se sobre a difícil capacidade de se ter fé. Como observador, coloca-se em um movimento contrário, dizendo não 
ser capaz de ter a fé de Abraão. Kierkegaard demonstra que não é fácil ter fé quando o exterior entra em contradição com a singularidade. Abraão não pode revelar a ninguém de sua incumbência, o que caracteriza a solidão de sua experiência, pois sua ação não está ancorada em uma ética, pela qual ainda consegue responder e legitimar suas ações. Diferente do Herói trágico, como Agamêmnon que responde e justifica suas ações conforme as leis estabelecidas, Abraão não pode repetir as leis éticas. Então, está diante de um abismo, porque aquilo que deve fazer é o oposto dos preceitos morais vigentes que regem a relação entre pai e filho.

A fé de Abraão se caracteriza pela inefabilidade que se encontra no limite da compreensão humana, no duplo movimento de abdicar e retomar: "pois é grande renunciar ao desejo, mas é maior apegar-se a esse desejo depois de haver dele abdicado; grande é agarrar o eterno, mas o maior é segurar o temporal depois de haver dele abdicado" (KIERKEGAARD, 2009b, p. 60). Nesse sentido, Abraão haveria de despir-se de significado, pois, pensando na promessa de sua geração, que teria seu início em Isaac, então qual seria o significado de Isaac se tivesse sido sacrificado? Kierkegaard ressalta que a fé de Abraão era uma fé que acreditava para esta vida, e por isso acreditava no irrazoável: de recuperar o significado do qual haveria de abdicar-se. Johannes, ao contrário, diz não conseguir penetrar no paradoxo da fé: "Não consigo fazer o movimento da fé, não consigo fechar os olhos e precipitarme cheio de confiança no absurdo, é para mim uma impossibilidade, mas não me orgulho disso (KIERKEGAARD, 2009b, p. 88). Abraão acreditava e acreditava por força do absurdo, pois acreditava que não seria bem-aventurado no além, mas, sim, que haveria de ser feliz neste mundo, pois Deus poderia dar-lhe um novo Isaac, chamá-lo à vida. Mas, objetivamente falando, para o raciocínio humano, era impossível. É nessa tensão entre a incerteza objetiva e a certeza subjetiva que nasce a fé. O movimento de abandono da finitude corresponde ao movimento da resignação infinita. Na resignação infinita, Abraão se abdica do amor e se reconcilia com a dor, mas a resignação infinita não é a fé; a fé consiste em não perder a finitude, mas ganhá-la por inteira. No movimento da fé "depois de fazer o movimento da infinitude, executa o da finitude” (KIERKEGAARD, 2009b, p. 93).

Para compreendemos este movimento da infinitude, passemos para O conceito de Angústia, obra publicada em 1844, e, portanto, posterior à obra Temor e tremor, em que, no capítulo 5, com o título Angústia como o que salva pela fé, Kierkegaard diz: 
A angústia é a possibilidade da liberdade, só esta angústia é, pela fé, absolutamente formadora, na medida em que consome todas as coisas finitas, descobre todas as suas ilusões. [...]. Aquele que é formado pela angústia é formado pela possibilidade, e só quem é formado pela possibilidade está formado de acordo com a sua infinitude (KIERKEGAARD, 2013b, p. 162)

A angústia é inerente ao humano e é o que nos coloca diante da possibilidade, enquanto possibilidade somos formados de acordo com a infinitude, pois a finitude está na realidade, mas a possibilidade está na infinitude. Assim, pela fé, o indivíduo é colocado diante da infinitude da possibilidade. Após descobrir todas as ilusões da finitude pela infinitude, o indivíduo retoma a finitude depois de a ela ter abdicado. A finitude retomada realiza a síntese com a infinitude, estabilizando a síntese. Kierkegaard afirma que a possibilidade é a mais pesada de todas as categorias (2013b, p. 162), é mais pesada que a própria realidade, pois na possibilidade estamos em uma instância na qual a realidade não está definida. A angústia "surge quando o espírito quer estabelecer a síntese, e a liberdade olha para baixo, para sua própria possibilidade, e então agarra a finitude para nela firmarse" (KIERKEGAARD, 2013b, p. 66). Ao querer estabelecer a síntese o indivíduo pode instaurar o desespero; pela fé, formado de acordo com a infinitude e retomando a finitude, o indivíduo estabelece a relação com aquele que o criou, mas a relação só é possível porque o amor vem ao encontro do indivíduo. Portanto, assim como a fé, o amor é outro conceito importante para compreendermos o significado da repetição na perspectiva religiosa. Segundo Roos, "um conceito de religião em Kierkegaard deve ser entendido colocando-se o conceito de amor como conteúdo do movimento da fé para a superação da falta de sentido advinda do desespero" (ROOS, 2019, p. 22). A fé necessita de um conteúdo, este é o amor. Se a fé não tem conteúdo, então bastaria Abraão ter dito que tinha fé, mas o que dá sentido à fé de Abraão é o amor que estava disposto a sacrificar e, na finitude, esperar receber Isaac novamente. Portanto, a fé diz respeito à decisão, ao duplo movimento de abandono e retomada, de realizar a síntese entre finitude e infinitude, portanto, não significa de modo algum a anulação do sofrimento. Segundo Roos: "O ponto central do conceito kierkegaardiano de fé não está no despojar-se, na resignação, mas, tomando o caso de Abraão, na crença de que obteria Isaac de volta depois de tê-lo abandonado" (ROOS, 2019, p. 20). Nesse sentido, tomando Abraão como paradigma da fé, objetivamente falando, era, para Abraão, impossível receber Isaac de volta. É nesse limite 
que a fé realiza a síntese entre finitude e infinitude; o amor é o conteúdo desse movimento que dá unidade à existência. Essas reflexões ainda hoje são preciosas para o ser humano, pois revelam a compreensão da complexidade e da profundidade da existência. Abraão tem a repetição ao receber Isaac novamente, pois uma vez que Isaac é recuperado, doravante Isaac passa a ter um novo significado para Abraão. A fé foi o que possibilitou, nesse sentido, a repetição. Segundo Roos: “[...] a fé não nega, mas ressignifica a existência humana como um todo (mesmo que não de forma total), incluídos aí, evidentemente, a finitude, a temporalidade e o corpo. " (ROOS, 2014, p. 352). A fé, ao ressignificar a existência como todo, possibilita a repetição.

Kierkegaard termina Temor e tremor, de forma que sua leitura tem relação com o conceito de repetição. Nesse sentido, além da obra $A$ repetição, de modo indireto, o conceito também está presente em Temor e tremor, onde fica mais evidente no epílogo da mesma obra:

Por muito que uma geração aprenda com outra, nenhuma geração aprende o que é especificamente humano com a anterior. Neste aspecto, cada geração começa de forma primitiva, a sua tarefa não é diferente da realizada pela geração anterior, também não chega mais longe a menos que a geração anterior atroçoasse a sua tarefa, enganando-se a si própria. Este especificamente humano é a paixão, na qual uma geração também entende inteiramente a seguinte e se entende a si mesma. Nenhuma geração aprendeu a amar com outra geração, nenhuma geração começa por outro ponto que não seja o princípio e nenhuma geração ulterior tem uma tarefa mais breve que a anterior, e se tal como aconteceu com as gerações anteriores não se quiser ficar aqui parado porque se ama, mas antes se avance, então esta conversa é meramente ociosa e sensaborona. (KIERKEGAARD, 2009b, p. 188)

Por mais que se possa aprender com uma geração anterior, aquilo que é especificamente humano, nossas questões mais fundamentais como o amor, a morte e a fé, jamais poderão ser aprendidas com a geração passada e com a tradição. Não superamos o luto porque outros, antes de nós, passaram por essa experiência. Não escapamos do sofrimento e do medo da morte e nem da alegria e do regozijo do amor porque todos aqueles que já existiram experimentaram esses sentimentos mais íntimos à existência. Cada qual, em sua época, haverá de atravessar por si mesmo seu próprio e único caminho. Nesse sentido, aquilo que é fundamental à religião, a experiência de fé, jamais poderá ser, por força do conhecimento, aprendida com Abraão. No âmbito existencial é excluída a possibilidade do progresso. A única herança herdada 
do passado é a sua própria missão enquanto possibilidade que já uma vez se deu (BOLLNOW, 1946, p. 182).

\section{Instante e Repetição}

No dia 13 de junho de 1844, quatro dias antes da publicação de $O$ Conceito de Angústia, Kierkegaard publica Migalhas Filosóficas, assinada pelo heterônomo Johannes Climacus. Segundo Alvaro Valls, "A expressão 'Migalhas' contém uma ironia contra a moda da época de se escreverem tratados sistemáticos ou, como diria nosso autor, sistemas de sistemas" (VALLS, 2012, p. 25). Essa oposição ao sistema é a oposição à necessidade de explicar tudo. Segundo Jon Stewart:

Migalhas filosóficas é um texto sobre a doutrina da encarnação e da revelação de Jesus Cristo. Mas Kierkegaard tem o cuidado de não mencionar Jesus pelo nome ou de fazer sua análise explicitamente nos termos do cristianismo. Ele fala simplesmente sobre 'o deus' de um modo que poderia se aplicar a qualquer religião revelada (STEWART, 2017, p. 182).

Lembrando que o tema da encarnação de Cristo, é o tema sobre o qual Martensen disse que não poderia ser compreendido sem a mediação. A mediação é o conceito que tenta superar a lógica do terceiro excluído. "A ideia de Kierkegaard aqui é uma resposta à ideia de mediação encontrada nas obras de hegelianos como Martensen" (STEWART, 2017, p. 183). Na lógica hegeliana não há contradições ou dicotomias absolutas, tudo pode ser mediado. Por exemplo, quando pensamos sobre o conceito de ser, podemos dizer que ele é pensado de forma independente ao conceito de nada. O mesmo acontece com o conceito de nada, que pode ser pensado de forma isolada do conceito de ser. Ambos os conceitos podem ser lidos como uma contradição, opostos de tal modo que a coexistência entre eles se torna impossível. No entanto, segundo a lógica de Hegel, o ser não pode ser pensado de forma isolada do conceito de nada e vice-versa. Desse modo, a relação entre eles é mediada e superada pelo conceito de devir, que é constitutivo do ser e do nada (STEWART, 2017, p. 58).

Nesse sentido, para Martensen, não há diferença absoluta entre o divino e humano, entre temporalidade e eternidade. Cada um desses termos está necessariamente relacionado com o outro e, desta forma, mediado por ele (STEWART, 2017, p. 183). A mediação, portanto, na perspectiva de Martensen, poderia explicar a encarnação de Cristo. Uma 
vez que não há diferença absoluta entre o humano e o divino, a encarnação pode ser compreendida pela mediação. Em Migalhas Filosóficas, Kierkegaard irá polemizar com essa afirmação de Martensen, opondo ao conceito de mediação, o conceito de paradoxo absoluto, o instante.

Lemos logo na epígrafe a pergunta que orienta as discussões na obra: "Poderá haver um ponto de partida histórico para uma consciência eterna; como poderá ele ter mais do que um interesse histórico; poderá erigir-se uma felicidade eterna sobre um saber histórico?” (KIERKEGAARD, 2012, p. 31). Podemos perceber que a pergunta de Climacus dá continuidade às discussões já elaboradas na obra É preciso duvidar de tudo,; se na obra anterior Climacus lança as bases para se pensar a relação entre idealidade e realidade, entendidas como eternidade e temporalidade, agora Climacus se propõe a investigar a relação entre o histórico e a eternidade. Em É preciso duvidar de tudo, a repetição é a contradição que une idealidade e realidade, sendo a consciência a forma dessa contradição. Em Migalhas a pergunta se volta para a verdade histórica, sobre como uma verdade histórica pode ser absoluta. Segundo Roos:

A dificuldade, que já havia sido percebida por Lessing, é a de que o cristianismo fundamenta-se em relatos históricos, portanto relativos e contingentes, mas quer fundamentar uma verdade que esteja para além de toda contingência, aquilo que, em Temor e tremor, é chamado de relação absoluta com o absoluto ou paixão e interesse infinitos. Há que se definir, portanto, os termos da relação entre histórico e verdade. Desse modo, o desenvolvimento propriamente dito de Migalhas inicia com a pergunta por como se aprender a verdade (ROOS, 2014, p. 355)

Portanto, há de se compreender aqui que uma verdade histórica é diferente de uma verdade metafísica. Uma verdade metafísica não pode ser diferente, por exemplo, quando dizemos que um quadrado tem quatro lados, é o fato de ter quatro lados que torna a figura um quadrado. Nesse sentido, o predicado está contido no sujeito. Se não pode ser de outra forma, é, portanto, uma verdade absoluta. Já uma verdade histórica é contingente, algo aconteceu, mas isso não significa que por ter acontecido não poderia ter sido de outra maneira. Portanto, uma verdade histórica resguarda a possibilidade de ter sido diferente, nesse sentido, ela não pode ser absoluta.

Por conseguinte, quando pensamos na encarnação de Cristo, pensamos enquanto um fato absoluto, pois na figura de Cristo há a união entre 


\section{Presley H. Martins \\ Renato Kirchner}

temporalidade e eternidade, de tal modo que esse fato histórico se torna absoluto; aqui há o paradoxo. A mediação não pode explicar esse fato (o paradoxo não se explica), só o explica à medida em que media os termos temporalidade e eternidade. Ao mediar temporalidade e eternidade, a mediação impede a transcendência, deixando tudo no plano da imanência, e no plano da imanência acaba transformando uma verdade histórica em uma verdade metafísica. Isso ocorre porque se considera o plano histórico a partir da necessidade metafísica, já que agora eternidade e temporalidade estão identificados. Segundo Roos: "O fato acontecido carrega em si a imutabilidade do histórico. Entretanto, a imutabilidade daquilo que aconteceu, do histórico, é diferente de uma necessidade metafísica" (ROOS, 2014, p. 357). Uma vez que algo aconteceu, há a necessidade histórica, mas não uma necessidade metafísica.

O que acentua o problema entre o histórico e o eterno é a condição do pecado, em outras palavras, a condição do indivíduo vir a estar na nãoverdade e necessitar encontrar a verdade. Em Migalhas, Climacus inicia pensando esse problema a partir de Platão (KIERKEGAARD, 2012, p. 44). A pergunta feita é: como podemos procurar pela verdade? Se já tivéssemos em posse da verdade não precisaríamos procurá-la, por outro lado, se não soubéssemos o que é a verdade, nem sequer a procuraríamos. Platão resolve esse problema a partir do conceito de reminiscência, ou seja, o indivíduo tem a verdade consigo, porém está esquecida e, portanto, deve apenas recordá-la. Nessa perspectiva o indivíduo está com a verdade, porém, a verdade está esquecida.

Existe algo decisivo à existência nessa reflexão de Kierkegaard. Em uma nota, Kierkegaard alude a uma criança que recebeu algum dinheiro e poderia comprar um bom livro ou um brinquedo, sendo que a criança escolhe o brinquedo. Ora, a criança não poderá comprar o livro com o mesmo dinheiro, pois o dinheiro já fora gasto, tampouco poderá trocar o brinquedo pelo livro, pois agora o brinquedo não tem o mesmo valor que o livro. Poderia ter no momento em que ela ainda tinha o dinheiro, mas depois de ter comprado já não tem mais (2012, p. 54). Imaginemos que o dinheiro é a possibilidade antes de uma escolha, depois de escolher não há como escolher o mesmo, uma vez que a escolha já foi feita. E aqui há uma imutabilidade do passado. Digamos que depois da escolha venha o arrependimento, mas estamos no tempo e não há como retornar e escolher diferente. Nesse sentido, se buscamos retroativamente a verdade, ela não poderá mais ser encontrada. Climacus diz: 
“A minha relação com Sócrates e Pródico não pode interessar-me tendo em vista a minha salvação eterna, pois que esta é dada retroactivamente na posse da verdade que eu tinha desde o princípio sem o saber" (KIEREKGAARD, 2012, p. 49). Aqui o instante não ganha uma significação decisiva, uma vez que o instante está no passado, o que se reafirma é o próprio arrependimento do menino em ter comprado o brinquedo ao invés do livro, por exemplo.

Nesse sentido, no pensamento platônico, o mestre é aquele que instiga o aprendiz a procurar a verdade. Portanto, ele é apenas a ocasião, porém, para descobrir a própria verdade, o aprendiz terá que fazer isso por ele mesmo. Todavia, ao descobrir que está na não-verdade, descobre também que ele é responsável por isso (KIERKEGAARD, 2012, p. 51-52). "E contudo o aprendiz é certamente não livre e está prisioneiro e excluído; pois que estar livre da verdade significa decerto estar excluído, e estar excluído por intermédio de si mesmo significa estar preso" (KIERKEGAARD, 2012, p. 53). Portanto, na perspectiva socrática, caso o indivíduo pudesse livrar a si mesmo de sua condição, o instante não teria significação decisiva, pois o instante seria dissipado no mesmo momento em que conseguisse livrar a si mesmo. Em oposição ao projeto socrático, para o instante ter uma significação decisiva, o indivíduo está na não verdade por sua própria culpa e não tem a condição de se libertar. Uma vez que ficou preso por meio de sua própria liberdade, ele não pode livrar-se a si mesmo. Conforme a ilustração, também o menino que compra o brinquedo ao invés do livro não consegue refazer a troca. Dessa forma, o instante tem significação decisiva, pois ele percebe as consequências de sua decisão em sua historicidade. Nesse sentido, ele não pode recuar para encontrar a verdade e se libertar. Climacus argumenta que aquele que é mera ocasião para verdade, mas não dá a condição para ela, não pode ser considerado mestre (KIERKEGAARD, 2012, p. 52). No entanto, aquele que devolve a condição da liberdade e, por conseguinte, a verdade ao aprendiz, é o salvador:

Entretanto, de acordo com a hipótese, o aprendiz não poderá libertar-se a si mesmo (E assim é também na verdade; porque ele usa a força da liberdade ao serviço da não- liberdade, uma vez que é de facto livre nela, e deste modo cresce a força concentrada da não-liberdade e faz dele um escravo do pecado.) - Como havemos então de chamar a um tal mestre, que lhe devolve a condição juntamente com verdade? Chamemos-lhe um salvador [..] (KIERKEGAARD, 2012, p. 55, grifo do autor). 
Para sair da perspectiva socrática, o discípulo deve ser a não-verdade (KIERKEGAARD, 2012, p. 57). Desse modo, o indivíduo pode ter sua liberdade novamente. O instante significa a irrupção da eternidade no tempo. Se no instante decisivo houver a má relação entre as categorias temporal e eterno, o indivíduo se torna escravo do pecado:

Chamemos agora a inverdade do indivíduo de pecado. Visto eternamente, ele não pode ser pecado, nem se pode pressupor que tenha estado eternamente nele. Portanto, nascendo (pois o início era, como se disse, que a subjetividade é a inverdade), ele se torna um pecador. Ele não nasce como pecador no sentido de ser pressuposto como pecador antes mesmo de ter nascido, mas nasce no pecado e como pecador. A isso poderíamos chamar, aliás, de pecado hereditário. Mas se a existência apoderou-se desse modo dele, então ele está impedido de retomar a si mesmo na eternidade pela reminiscência (KIERKEGAARD, 2013c, p. 219)

Compreendendo o pecado enquanto desespero, o indivíduo não pode ser pressuposto como pecador, pois caso fosse, seria dizer que o desespero é inerente ao humano. Se o desespero fosse inerente à natureza humana, então não haveria possibilidade de cura. O pecado surge por um salto. Portanto, devido ao pecado, o indivíduo não pode recuar para estar de posse da verdade. Nesse sentido, a verdade precisa ser encontrada em sua existência:

Se já Sócrates havia percebido como era complicado, especulando, abstrair-se da existência e remontar à eternidade, quando nenhuma complicação havia para o existente senão o fato de que ele existia, além de que o existir fosse o essencial: agora ficou impossível. Ele precisa andar para a frente; recuar é impossível (KIERKEGAARD, 2013c, p. 220)

Constantius diz que a repetição e a recordação têm o mesmo movimento, porém em direções opostas. Se a recordação é o movimento retroativo, então a repetição é o movimento para a frente. Isso significa dizer que para o indivíduo sair de sua condição de pecado, ele necessita da repetição. A única forma da liberdade ser restaurada é restabelecer a síntese entre possibilidade-necessidade. Nesse sentido, somente um salvador pode libertar e devolver a verdade ao indivíduo. Essa verdade não pode ser retroativa, a verdade eterna precisa estar na existência.

A verdade eterna surgiu no tempo. É isso o paradoxo. Se o sujeito acima mencionado foi impedido pelo pecado de retomar-se a si mesmo na 
eternidade, agora não deve mais se preocupar por causa disso, pois agora a verdade eterna, essencial, já não se encontra lá atrás, mas veio para a frente dele, pelo fato de ela mesma existir, ou ter existido, de modo que se o indivíduo, existindo, na existência, não alcançar a verdade, jamais a alcançará (KIERKEGAARD, 2013c, p. 220)

Mas como pode a verdade eterna ir ao encontro do indivíduo se ambos são absolutamente diferentes? Em Migalhas filosóficas, o amor é o que faz o mestre ir ao encontro do discípulo: "porque só no amor se transformará o diferente no igual, só na igualdade ou na unidade há entendimento..." (KIERKEGAARD, 2012, p. 66). E isso só é possível através do amor que transforma o diferente em igual, do eterno que se temporaliza. Dessa forma, o instante, o eterno no tempo, que possibilita a recuperação do si-mesmo, acontece pela fé que requalifica o passado na subjetividade. Isso significa dizer que ao sair da condição da não verdade para verdade, o indivíduo renasce, uma vez que aquilo que ele havia perdido, foi novamente dado a ele através do amor. Desse modo, o instante possibilita a repetição, uma vez que faz renascer o indivíduo na recuperação de sua liberdade. O Paradoxo absoluto, acentua a existência e torna o indivíduo presente a ele mesmo novamente. Nesse sentido, o menino pode escolher novamente entre o livro e o brinquedo, sabendo que sua decisão anterior o deixou na não verdade, agora haverá de escolher o livro. Portanto, uma necessidade história, a partir dessa relação com o instante, pode ser reconfigurada, restaurada. Uma necessidade metafísica não poderia obter essa restauração.

\section{Amor e Repetição}

Em dinamarquês há duas expressões para a palavra amor; Elskov significa a dimensão erótica, natural e apaixonada; Kjerlighed, expressa um amor mais elevado e abrangente. Publicado em 1847, As obras do Amor fala do amor cristão, do amor que se reconhece por seus frutos, cuja essência é impenetrável, mas que conhecemos, sabemos da sua existência, a partir de seus frutos. Nessa obra Kierkegaard analisa o amor ao próximo enquanto dever: "tu deves amar o próximo como a ti mesmo". A fim de ressaltar a peculiaridade do significado do amor cristão, Kierkegaard o diferencia do amor imediato, do amor romântico: essas formas de amor podem mudar em si mesmas; o amor pode transformar-se em ódio, obsessão e em ciúmes, mas o amor ao próximo torna-se eterno com o dever. Kierkegaard 
explica que dizer para o poeta "tu deves amar" seria sufocar o amor com a imposição, pois o amor deve ser livre para amar, mas Kierkegaard explica que tal compreensão é um equívoco, pois o amor que o poeta proclama é justamente este amor que sofre alteração, mas só quando amar é um dever, só então está eternamente assegurado contra qualquer mudança (KIERKEGAARD, 2013a, p. 45). Nesse sentido, a mudança não está somente relacionada a quem se ama, mas também na mudança de quem ama, pois este não tem continuidade, não tem um si-mesmo que faça o amor ser contínuo e o mesmo nas mudanças.

Kierkegaard irá dizer que o mandamento "Tu deves amar o teu próximo como a ti mesmo", também pode ser entendido como "Tu deves amar a ti mesmo da maneira certa" (2013a, p. 38). Nesse sentido, para amar o próximo deve-se aprender a amar a si mesmo da maneira correta. Se o eu sofre com o desespero, com a falta de sentido, e não tem um si-mesmo, como poderá amar o próximo como a ti mesmo? Kierkegaard diz: "A Lei é, portanto: Tu deves amar a ti mesmo da maneira como tu amas ao próximo, quando tu o amas como a ti mesmo" (KIERKEGAARD, 2013a, p. 38). Esse "quando tu o amas como a ti mesmo", é o momento em que o eu tem um si-mesmo. Quando tem um si-mesmo, então poderá amar ao próximo, assim o eu deverá amar-se da maneira como ama o próximo.

Não é para ter um si-mesmo que amo o próximo, pois essa forma de amor é condicional, mas quando tenho um si-mesmo pela fé - e aqui significa que já recebi o amor e preciso acreditar nele -, então amo ao próximo. Ter um si-mesmo assegura o amor ao próximo e, ao amar o próximo dessa forma, estou amando a mim mesmo da maneira correta. O si-mesmo e o próximo não podem estar separados. Kierkegaard argumenta que: "Quem tem algum conhecimento dos homens vai certamente confessar que muitas vezes, assim como desejou poder motivá-los a renunciar o amor de si, assim também muitas vezes precisou desejar se possível ensinar-lhes a se amarem a si mesmos" (KIERKEGAARD, 2013a, p. 38). Nesse sentido, renunciar o amor de si significa renunciar ao amor egoísta, e o ensinar a amar a si mesmo, é ensinar o amor que se fundamenta no dever de amar o próximo.

O amor romântico como, por exemplo, o amor do Jovem, não produz sentido na existência, pois esse amor é inconstante. Na obra A Repetição, o amor é pensado em sua forma poética. Por isso, o Jovem perde o sentido da sua vida ao não ser mais correspondido por sua amada. Ao perder a amada, perdeu a si mesmo, mas perdeu a si mesmo porque não tinha um si-mesmo. 
Portanto, o amor que liberta e que vem de encontro ao indivíduo é o amor encarnado, o amor que se torna semelhante. Segundo Roos: "Aqui, contudo, é preciso dar um passo adiante e mostrar que o paradoxo cristológico do infinito no finito deve ser interpretado a partir do conceito de ágape, de modo que o paradoxo seja entendido, no limite, como a encarnação do amor" (ROOS, 2019, p. 23). Nesse sentido, o amor ao próximo tem seu fundamento no amor que recebemos do salvador, do amor que restaura a liberdade, assim faz com que sejamos livres para amar o próximo.

Para Kierkegaard é esta ação o que dá unidade ao indivíduo, pois o mantém na horizontalidade da finitude, ao amar o próximo, mas simultaneamente a partir de um fundamento infinito, ao fundamentar a relação para com o próximo no amor mesmo. Em outras palavras, o conceito de amor, partindo da tradição cristã como aquele que une em si finitude e infinitude, temporalidade e eternidade, é justamente a chave para a compreensão da superação do desespero, da superação da cisão humana entre finitude e infinitude, da superação do si-mesmo consigo mesmo (ROOS, 2019, p. 26).

O amor ao próximo é a única forma de amor que realiza a síntese de finitude e infinitude, uma vez que não é um amor objeto de predileção, não é dependente de uma pessoa específica. Ele se mantém o mesmo na multiplicidade. O amor pela predileção não se diferencia, diz Kierkegaard, do amor pagão. Ademais, o amor ao próximo é o que dá unidade e continuidade na interioridade. Dessa forma, é o que dá sentido à existência. Nesse sentido, tornar-se si-mesmo compreende a relação que se estabelece com o próximo. Lutero, por quem Kierkegaard fora influenciado ${ }^{10}$, em sua obra Da Liberdade do cristão, lança luz para compreendermos a argumentação sobre o dever do

10 Segundo Roos, "Kierkegaard cresceu em um contexto luterano, estudou teologia numa faculdade luterana, e, ao longo de sua vida, por diversas vezes pensou em ser pastor em alguma comunidade no interior da Dinamarca. Para além disso, sua obra é rica em modos de pensamento remanescentes ao reformador" (2018, p. 148). No texto, Roos também argumenta sobre a relação polêmica de Kierkegaard com Lutero e, principalmente, com o luteranismo dinamarquês. Um ponto que pode nos orientar sobre essa questão é: "A questão central é que Lutero experimentou em sua vida uma grande angústia religiosa e uma profunda consciência do pecado. Como resposta a esta situação, encontrou a mensagem da justiça de Deus como algo que se oferece, ou seja, a centralidade e unicidade da graça operada por Cristo. Kierkegaard está de acordo com tudo isso. O problema surge quando este modo de entender o cristianismo, que parte de uma experiência pessoal e contextualizada, se torna um paradigma a pessoas que estão fora do contexto daquela experiência determinada" (ROOS, 2018, p. 150). 
amor ao próximo. Nessa obra Lutero escreve sobre a liberdade que Cristo proporciona ao ser humano. Inicia com duas conclusões retiradas de São Paulo: "Um cristão é um senhor livre sobre todas as coisas e não se submete a ninguém. Um cristão é um súdito e servidor de todas as coisas e se submete a todos" (LUTERO, 1998, p. 25).

As duas conclusões que parecem ser contraditórias são, na verdade, complementares. Para compreender as conclusões é necessário entender a distinção que Lutero faz entre o homem corporal e o homem espiritual; o homem possui essa natureza dupla. O homem corporal é chamado, segundo a carne e o sangue, de o homem velho e exterior, e o homem espiritual, segundo a alma, é o homem novo e interior. Segundo Lutero: “evidenciase que nenhuma coisa exterior, seja qual for o seu nome, pode torná-lo justo ou livre, pois sua justiça e sua liberdade, inversamente sua maldade e sua prisão, não são corporais nem externas" (LUTERO, 1998, p. 25). Isso significa que, para uma alma aprisionada, não basta o corpo ser livre, pois não poderá libertar a alma, nem a tornar justa ou má (LUTERO, 1998, p 27). Nesse sentido, as obras não podem libertar a alma. No Prefácio À Epistola de São Paulo aos Romanos, Lutero irá dizer que ninguém cumpre a Lei de Deus porque todos encontram dentro de si mesmos a indisposição para o bem (1998, p. 85). Lutero, na obra Da Liberdade do cristão, destaca que na Sagrada Escritura as palavras estão divididas de dois modos: os mandamentos ou leis de Deus e a promessa ou compromisso.

Segundo Lutero, o Antigo Testamento é a Lei, sendo que leis orientam, mas elas mesmas não ajudam na prática, nelas reconhecemos nossa insuficiência e nossa incapacidade de cumpri-las. Já o Novo Testamento é a palavra da promessa (1998, p. 31-33). A Lei diz respeito ao espírito e é pelo espírito que se deve cumpri-la. As obras, que estão relacionadas ao corpo, não podem libertar o espírito. Então, se as obras não podem libertar a alma do pecado e, ao mesmo tempo, não conseguimos cumprir a Lei, como ficamos livres do pecado? Segundo Lutero, pela graça somos justificados por Cristo. A graça é a pregação de Cristo tal como contida no Evangelho, que é a palavra da promessa (LUTERO, 1998, p. 29). Mas para sair da perdição, deve entregar-se com fé inquebrantável na Palavra viva e consoladora de Cristo: "Desse modo, pela fé, todos os teus pecados serão perdoados, toda a tua perdição será sobrepujada e tu serás justo, verdadeiro, repleto de paz, íntegro, cumpridor de todos mandamentos e livre de todas as coisas [...]" (LUTERO, 1998 , p. 29). Se estamos justificados pela fé, então nada precisamos fazer 
para nos justificar, "de modo que mandamento e cumprimento pertencem unicamente a Deus, só Ele ordena e só Ele cumpre” (LUTERO, 1998, p. 33).

Lutero enfatiza que as obras não podem justificar porque a intenção nas obras faz com que elas se tornem egoístas. Se faço algo ao próximo tendo em vista ganhar minha salvação, então eu não o amo, pois minhas ações estão condicionadas. Este ponto é fundamental para compreender que sem a fé, o amor é egoísta. Portanto, somente a fé pode tornar o ser humano livre de suas ambições e, ao mesmo tempo, fundamentar o amor ao próximo, pois já recebemos, pela graça, o amor que nos liberta. Sem a fé, o amor ao próximo é a Lei que não conseguimos cumprir por nós mesmos, que mostra nossa insuficiência. Mas, pela fé - além das explicações - o amor ao próximo se torna possível. No entanto, o fato de já estarmos livres do pecado e justificados por Cristo através da fé, não significa que as obras não serão realizadas, pelo contrário: livre do egoísmo, "um cristão é um senhor livre sobre todas as coisas e não se submete a ninguém" (LUTERO, 1998, p.25). Agora podemos realizar as boas obras: "um cristão é um súdito e servidor de todas as coisas e se submete a todos" (LUTERO, 1998, p. 25). É nesse sentido que o amor ao próximo é um dever para o cristão. Segundo Roos: "No dever de amar o próximo, a regra de ação passa a encontrar-se na interioridade do indivíduo, de modo que ele vem a ser independente em relação ao objeto do amor e, precisamente por isso, pode amar ao próximo" (ROOS, 2019, p. 24).

Kierkegaard apropria-se dessa dialética da Lei e da promessa ${ }^{11}$ e está presente em suas Obras do amor. A independência do amor está assegurada pela eternidade e, por isso, é contínua na mudança. O dever no amor cristão diferencia-se de uma ética imanente, pois é um dever transcendente que passa pela alteração da eternidade. E para compreender o dever na alteração da eternidade, recorremos à fé que, ao passar pela angústia, na infinitude da possibilidade, descobre todas as ilusões do amor finito - que sofre alteração - e retorna para a finitude como dever e continuidade eterna. Edna e Howard Hong, escrevem no prefácio das Obras do amor que:

A característica fundamental do amor cristão diferencia-se de um sentimento ético qualquer. Além disso, a implícita diferença entre o imperativo ético, como está no discurso do coração puro na segunda parte da obra $\mathrm{O} u-O u$ e

11 Segundo Roos, "a dependência de Kierkegaard com relação a Lutero se dá em torno da dialética de lei e evangelho, que herda do reformador" (ROOS, 2018, p. 148). 
em partes de Temor e Tremor, demonstra a distinção do amor cristão de uma ética filosófica imanente [...] (HONG, 1995, p. 10-11, tradução própria)

A distinção do amor cristão em relação ao amor ético imanente é que não se pode reconhecer o fruto pelas normas que regem determinado comportamento, pois, em um certo sentido, aquele que realiza as boas obras pode ser movido somente pela vaidade, por interesse egoísta e, dessa forma, o dever não sofreu a alteração da eternidade, mas permaneceu preso na finitude. Por isso, aqui faz-se necessário a fé para transcender a finitude e retomá-la na sua integridade. Neste ponto, cabe lembrar que a ética diz a Abraão que não se deve matar, mas amar seu filho; do ponto de vista ético, Abraão está prestes a se tornar assassino, mas, pela fé, sua ação torna-se um ato de amor, de continuidade na mudança.

Abraão se coloca na relação absoluta com o absoluto, transcendendo a ética imanente. Nesse sentido, seu amor ao próximo é incompreendido pelo dever da ética imanente, no entanto, não deixou de amar ao próximo. A ação em si nada significa, mas é significada na interioridade por quem ela é realizada. O mandamento "tu deves amar o próximo como a ti mesmo", significa a transfiguração de si-mesmo no próximo. Segundo Kierkegaard: "para Cristo não se trata de saber quem é o próximo, mas sim de a gente mesmo se tornar o próximo, e que a gente demonstre ser próximo como o Samaritano o provou em sua misericórdia" (2013a, p. 38). A transfiguração de si-mesmo no próximo ocorre pela fé. O indivíduo já tendo recebido o amor e a sua liberdade, não está determinado em sua subjetividade, nem preso ao passado, pois a eternidade se faz presente no tempo; pela via da fé, une no amor a finitude e infinitude, a temporalidade e a eternidade, a necessidade e a possibilidade, podendo ser si-mesmo, relacionando os termos que o constituem. Assim, pode amar incondicionalmente e coloca-se como igual diante daquele que, como no caso do samaritano, necessita de misericórdia. Nesse sentido, Kierkegaard afirma: "Tu deves amar. Só quando amar é um dever, só então o amor está eternamente assegurado contra qualquer mudança; eternamente libertado em bem-aventurada na independência; protegido eterna e felizmente contra o desespero" (KIERKEGAARD, 2013a, p. 45, grifo do autor). Desse modo, as mudanças exteriores não alteram a continuidade do amor, este é independente das condições, pois está relacionado com a fé que transcende as ilusões finitas; a fé, por sua vez, só é possível pelo amor que recebemos e nos faz renascer como um si-mesmo, somente quando há um si-mesmo é 
que o dever de amar o próximo é interiorizado. E é somente na interioridade que podemos produzir sentido na existência, pois agora há continuidade, há repetição no amor ao próximo.

\section{Conclusão}

Neste texto buscamos pensar a categoria repetição, assim como elaborada por Søren Kierkegaard, em articulação com outros conceitos do autor, que são cruciais à compreensão da repetição em seu sentido religioso. Desse modo, a possibilidade de construção de sentido na existência ocorre mediante a repetição enquanto categoria religiosa. Assim, vimos que a realização plena da repetição ocorre no amor ao próximo, uma vez que esse amor é o mesmo em situações distintas. O amor é imutável na temporalidade, imutável no movimento e nas mudanças do devir. Nesse sentido, o amor repete-se, e essa repetição proporciona sentido. Se o sentido é perdido na contingência, no amor ele é recuperado. Somente quando algo de fundamental à existência é perdido, é que o sentido pode aparecer. Portanto, o conceito de religião em Kierkegaard se fundamenta nessa perspectiva de recuperação de sentido e não pode ser compreendido sem as categorias de fé, amor, instante e repetição. Pensar a repetição em Kierkegaard é pensar profundamente a religião em seu pensamento. Ademais, é na religião que a repetição é possível, uma vez que a religião transcende o movimento imanente a partir de seus conceitos fundamentais: fé e amor.

Percebemos que a compreensão sobre a categoria repetição é complexa porque se relaciona com outros conceitos do autor. Embora o próprio Kierkegaard tenha escrito uma obra com o título $A$ Repetição, esta apenas direciona um caminho no labirinto de sua autoria, pois, o que percebemos em sua obra é a negatividade do conceito, ou seja, Kierkegaard não define a categoria repetição de uma forma direta. O pseudônimo da obra, ao tentar experimentar a repetição, chega à conclusão de que a repetição não existe. O Jovem, porém, tem a intuição da repetição a partir do livro de Jó. Nesse sentido, a repetição é melhor explicada quando articulada a outros conceitos.

O sentido não pode ser encontrado retroativamente, mas deve ser buscado na existência. A repetição busca o sentido na existência, no presente. Desse modo, percebemos que o Paradoxo absoluto, entendido como a eternidade no tempo, retira o indivíduo da sua condição de não-verdade e reestabelece a síntese constitutiva do seu eu, devolvendo-lhe a liberdade. A fé retoma a temporalidade em seu duplo movimento, recuperando o que 
havia sido abdicado. Compreendendo conjuntamente esses conceitos, temos a repetição, que encontra sua maior expressão no amor ao próximo.

A religião no pensamento de Kierkegaard não pode ser vista como uma função ou aspecto da existência, mas podemos pensá-la como o próprio fundamento da existência. Essa argumentação acompanha, ao mesmo tempo, as considerações feitas sobre Jó. O sofrimento de Jó, no limite, corresponde ao sofrimento humano. Uma vez que Kierkegaard concebe o ser humano como constituído de temporalidade-eternidade, necessidade-possibilidade, finitude e infinitude, somente uma relação transcendente poderá realizar a síntese na existência. Esses termos como pensados por Kierkegaard não estão aquém de nossas experiências cotidianas, mas são constitutivos delas. Para o ser humano ser si-mesmo, ter continuidade na contigência, ele precisará realizar a síntese que o constitui. Nesse sentido, somente conseguirá realizar tal tarefa a partir de categorias religiosas, como apresentadas neste texto. Essas categorias são, ao mesmo tempo, existenciais. Por fim, cabe ao indivíduo decidir, transformar-se, renascer, repetir-se, pois o amor eterno foi ao seu encontro quando o indivíduo estava no desespero.

\section{Referências}

BOLLNOW, Otto F. Filosofia Existencial. Porto: Imprensa Portuguesa, 1946.

DELEUZE, Gilles. O que é a filosofia? 3. ed. São Paulo: Editora 34, 2010.

GARDINER, Patrick. Kierkegaard. São Paulo: Loyola, 2013

GARFF, Joakim. Kierkegaard's Muse: the mystery of Regine Olsen [livro eletrônico]. Oxford: Princeton University Press, 2017

GOUVÊA, Ricardo Quadros. Paixão pelo paradoxo: uma introdução à Kierkegaard. 1. ed. São Paulo: Novo Século, 2000.

KIERKEGAARD, Søren. A repetição. Tradução, introdução e notas de José Miranda Justo. Lisboa: Relógio D’Água, 2009a.

Temor e Tremor. Tradução, introdução e notas de Elisabete M. de Souza. Lisboa: Relógio D’água, 2009b.

Migalhas Filosóficas. Lisboa: Relógio d’Água, 2012.

As obras do amor. 4. ed. Petrópolis, RJ: Editora Vozes, 2013a

O conceito de angústia. 3. ed. Petrópolis, RJ: Vozes; Bragança Paulista, SP:

Editora Universitária São Francisco, 2013b.

Pós-escrito às migalhas filosóficas. Vol. I. Petrópolis, RJ: Editora Vozes, 2013c. 
. O desespero humano (Doença até à morte). 5. ed. São Paulo: Editora Livraria Tavares Martins, 1961.

Works of love. Ed. e trad. Introdução e notas de Howard V. Hong e Edna H. Hong. New Jersey: Princeton University Press, 1995. (Versão eletrônica).

Eighteen Upbuilding Discourses. Ed. e trad. com introdução e notas de Howard V. Hong e Edna H. Hong. New Jersey: Princeton University Press, 1992. (KW V). (Versão eletrônica).

LUTERO, Martinho. Da liberdade do cristão (1520). São Paulo: Fundação Editora da Unesp, 1998.

MOONEY. Edward F. Repetition: Getting the World Back. IN: MARINO, Gordon D. (Eds.). The Cambridge Companion to Kierkegaard. New York: Cambridge University Press, 2006. (Cambridge Companions Series).

MOONEY, Edward F. Repetition and philosophical crumbs. Oxford: Oxford University Press, 2009. (Versão eletrônica).

ROOS, Jonas. Finitude, infinitude e sentido: um estudo sobre o conceito de religião a partir de Kierkegaard. Brasília: Revista Brasileira de Filosofia da Religião, v. 6, p. 10-29, 2019.

. Kierkegaard, Lutero e o Luteranismo: Polêmica e Dependência. Brasília: Revista de Filosofia Moderna e Contemporânea, v. 5, p. 147-170, 2018.

Religião, Temporalidade e Corporeidade em Kierkegaard. Juiz de Fora: Numen: revista de estudos e pesquisa da religião, v. 17, p. 1-308, 2014.

STEWART, Jon. Soren Kierkegaard: subjetividade, ironia e a crise da modernidade. Tradução Humberto Araújo Quaglio de Souza. Petrópolis: Vozes, 2017.

VALLS, Alvaro. Kierkegaard: cá entre nós. São Paulo: Editora LiberArs, 2012.

Submetido em: 19-2-2021

Aceito em: 11-10-2021 